\title{
Optimal engineered algae composition for the integrated simultaneous production of bioethanol and biodiesel
}

\author{
Mariano Martín ${ }^{\mathrm{a}, 1}$, Ignacio E. Grossmann ${ }^{\mathrm{b}}$ \\ aDepartamento de Ingeniería Química. Universidad de Salamanca. Plz. Caidos 1-5 37008 Salamanca (Spain)

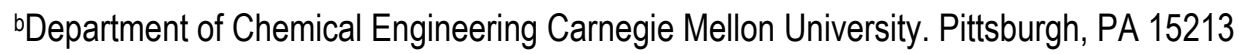

\begin{abstract}
.
In this paper we present the optimization of the composition of the algae for the simultaneous production of bioethanol and biodiesel. We consider two alternative technologies for the biodiesel synthesis from algae oil, enzymatic or homogeneous alkali catalyzed, the most promising based on previous work, and we coupled biodiesel production from oil with bioethanol production from algae starch. In order to determine the optimal operating conditions we not only couple the technologies, but simultaneously optimize the production of both biofuels and heat integrate them. Multieffect distillation column for the beer column is included in the flowsheet to mitigate the energy and cooling water consumption derived from the ethanol dehydration. In both cases the optimal algae composition results in $60 \%$ oil, $30 \%$ starch and $10 \%$ Protein. The cheaper alternative for the production of biofuels corresponds to a production price of $0.35 \$ / g a l$, using the enzymatic catalyzed path with promising energy and water consumption values $(4.20 \mathrm{MJ} / \mathrm{gal} \& 0.61 \mathrm{gal} / \mathrm{gal})$.
\end{abstract}

Keywords: Energy; Biofuels; Bioethanol; Biodiesel, Process integration

\footnotetext{
${ }^{1}$ Corresponding author. Tel.: +1-412-268-3642; Fax: +1-412-268-7139.

Email address: mariano.m3@usal.es; grossmann@.cmu.edu
} 


\section{INTRODUCTION}

Biofuels are typically classified by the raw material they use. Thus, corn, vegetable oil and sugar cane are the raw material for what has been called as first generation fuels. These raw materials have the disadvantage that compete with the food supply chain, not only for the land usage for its production but also in the final product destination, food or biofuel. In order to overcome these drawbacks, the second generation of biofuels comprises those raw material that are not used as food product but also, do not compete in land with the food supply chain since they can be grown in marginal areas or wastes from other industries. In this group we find lignocellulosic raw material such as switchgrass, which can be grown in most of US territory with good yield, forest residues, corn stover or cooking oil. (Nigam and Singh, 2010).

The high demand for liquid fuels poses a huge burden on this second generation of biofuels due to the limited availability of land and wastes on earth. Eventually, there may be a replacement of the use of land for growing energy crops that will affect the food chain leading to food scarcity (Donner and Kucharik, 2008; Fargione et al., 2008; Landis et al., 2008; Searchinger et al.,2008). Cultivating trees and grasses for biofuels may compete with agriculture intended to supply food, feed and fibre to an expanding world population (Sheehan, 2009).

In spite of the promising results presented in the literature for the lignocellulosic based ethanol, FT-diesel (Aden 2002, Phillips et al 2007, Dutta \& Phillips 2009, Martin \& Grossmann 2011 a,b,c,d) in terms of energy and water consumption and low production cost algae are gaining attention as an alternative source of renewable biomass to increase the production of biofuels and meet the government policies. The use of algae as energy feedstock is not new as it can be traced back to the 1950s (Chen et al., 2009). Its main growth took place during the oil crisis of 1970s and the US Department of Energy has been funding research at the National Renewable Energy Lab (NREL) for more than two decades. The low cost of crude oil closed the program back in 1996 but since then much has changed (Chen et al., 2009, Waltz, 2009, Knoshaug, \& Darzins 2011). The great advantage of algae is that they can sequester $\mathrm{CO}_{2}$ that is used as carbon source for the production of biomass, so that these plants can be used alongside fossil fuel power stations (Sawayama et al., 1995; Brown and Zeiler, 1993), or even the $\mathrm{CO}_{2}$ generated in the production of bioethanol, hydrogen or FT-diesel from lignocellulosic materials (Martín \& Grossmann 
2010, 2011a,b). Furthermore, the composition of the algae dry matter can be adjusted depending on the algae species and the growth procedure. For instance, microalgae exhibit a great variability in lipid content. Among microalgae species, oil contents can reach up to $80 \%$ such as the Botrycoccus and levels of $20-50 \%$ are quite common in Chlorella species (Powell and Hill, 2009). The variations are due to different growing conditions and methods of extraction of lipids and fatty acids. Moreover, microalgae like Chlorella, Dunaliella, Chlamydomonas, Scenedesmus, Spirulina are known to contain a large amount of starch and glycogen ( $>50 \%$ of the dry weight), that can be used as raw materials for ethanol production (Ueda et al., 1996). Microalgae can also assimilate cellulose which can also be fermented to bioethanol (Chen et al., 2009).

In a recent paper by Severson et al. (2012), it was shown that the use of bioethanol for the production of biodiesel may be competitive with the use of methanol for a production price of ethanol lower than $\$ 0.5 / g a l$. Thus, it is possible to simultaneously define the optimal algae composition together with the integrated production of biodiesel and bioethanol, using part of the bioethanol as transesterifying agent.

In this paper we propose the simultaneous optimization and heat integration for the production the two major biofuels, bioethanol and biodiesel. We evaluate the two most promising processes for the production of biodiesel using ethanol, alkali and enzymatic catalyzed ones from Severson's et al. (2012) paper. We first simultaneously optimize and heat integrate the process from the algae growth to oil extraction, starch depolymerization into glucose and its fermentation to ethanol followsed by its dehydration and the trasnesterification of the oil with ethano. Then, we design the optimal water network to determine the water consumption of the flowsheets, and finally we perform an economic evaluation to fully compare the integrated process with the stand alone process that uses methanol (Martin \& Grossmann, 2012) so that we can compare both transesterification agents. The paper is organized as follows. We describe first the entire superstructure with the different steps involved in the production of oil from algae, bioethanol and biodiesel. Next we present the main features of the models. The third part considers the objective function and the solution procedure followed by the results, and the comparison between this integrated process and the use of methanol. 


\section{PROCESS TECHNOLOGIES}

Figure 1 shows the simplified superstructure flowsheet for the integrated production of bioethanol and biodiesel from algae. First algae are grown in ponds. Next, by using an organic solvent we extract the oil and separate the starch. On the one hand, the starch is saccharified and liquified for the production of ethanol. In parallel the oil is transesterified using the dehydrated ethanol. We consider the two most promising alternatives for the transesterification of oil using bioethanol from Severson et al (2012), the use of a homogeneous alkali catalysts or the enzymatic catalyzed reaction. The ethanol is recovered, reclycled and mixted with part of the ethanol produced from the starch and the gycerol is separated from the product biodiesel, in this case fatty acid ethyl ester (FAEE).

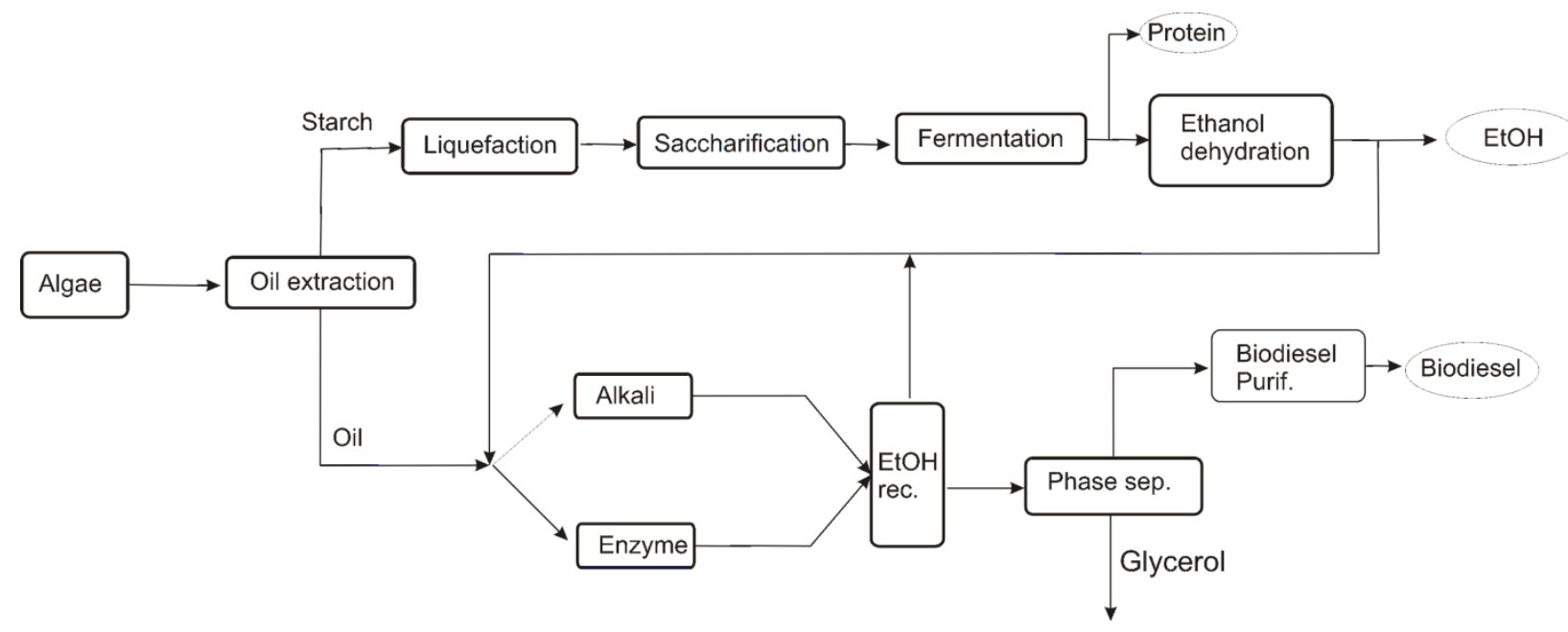

Figure 1. Superstructure for the production of bioethanol and biodiesel from algae

The units are modeled using reduced order models based on experimental data from the literature, mass and energy balances, rules of thumb and design equations. The superestructure is formulated in terms of the total mass flows, component mass flows, component mass fractions, and temperatures of the streams in the network. The components in the system include \{ Water, Ethanol, Glycerol, FAEE, FFA, Oil, Hexane, Starch, Glucose, Maltose, Protein, Succinic Acid, Acetic Acid, Lactic Acid, Urea, NH3, H2SO4, KOH, K2SO4, H3PO4, K3PO4, Algae, Biomass, $\mathrm{CO} 2, \mathrm{O} 2\}$. Here we only present the main features of the units. For further details of the models we refer the readore to previous papers (Karuppiah et al 2008, Martín \& Grossmann 2012, Severson et al 2012). 
Duran \& Grossmann (1986) showed that the simultaneous optimization and heat integration can yield significant energy and cost savings. In this process the recycle of ethanol requires large amount of energy, and therefore this motivates the integration of the model presented by Duran \& Grossmann (1986) in the problem formulation. The water consumption of this process is thus also optimized by integrating the energy and designing the optimal water network based on the results reported by Ahmetovic et al. 2010 and Grossmann \& Martín 2010.

\section{Algae production}

Figure 2 shows the flowsheet for the production of oil and starch from algae (Martín \& Grossmann 2012). The production of oil from algae is performed by injecting $\mathrm{CO}_{2}$ into the water, which can be saline water so that the consumption of freshwater is reduced, together with air and fertilizers. The amount of water needed, the concentration of fertilizers is taken from the report by Pate (2008) while the consumption of $\mathrm{CO}_{2}$ depends on the growth rate, typically $50 \mathrm{~g} / \mathrm{m}^{2} \mathrm{~d}$ (Schenket et al., 2008), and is given by the experimental results by Sazdanoff (2006). Together with the algae, oxygen is produced and water is evaporated (Pate, 2008). The energy consumed by the pond system is calculated based on the results by Sazdanoff (2006). Next, the algae are harvested from the pond. Recently Univenture inc. has presented an innovative technology capable of integrating harvesting and drying the algae with low energy consumption. It is based on the use of capillarity, membrane systems and paint drying to get $5 \%$ wet algae with a consumption of $40 \mathrm{~W}$ for $500 \mathrm{~L} / \mathrm{h}$ of flow. The biomass is mixed with cyclo-hexane and pressed so that oil is extracted, and the biomass is separated from the oil. The biomass is sent to liquefaction and saccharification and as we present in the following section while the oil is used for trasnesterification and biodiesel production. 


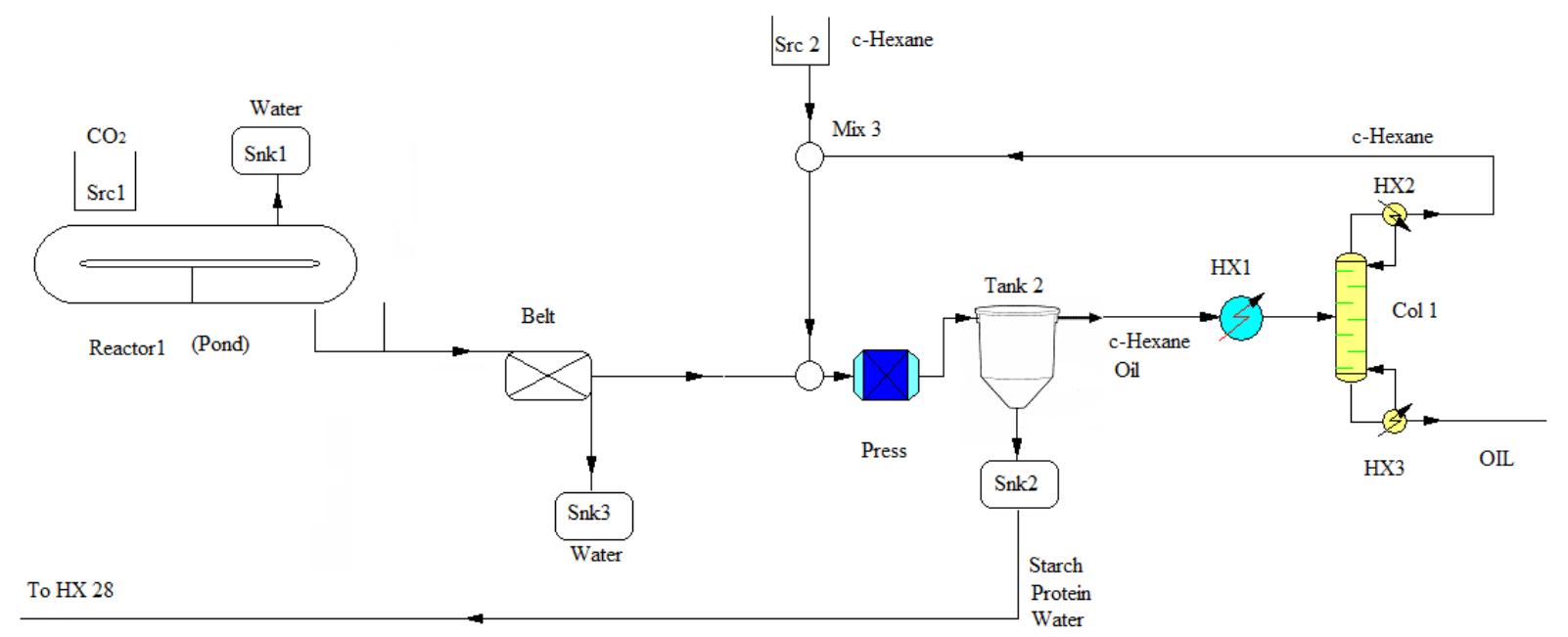

Figure 2. Algae growing and harvesting followed by oil extraction

One key variable for the process is the ratio starch/oil. This is highly variable depending on the algae species, as well as on the growing conditions (John et al., 2010). Dragone et al 2011 studied the conditions to regulate the concentration of starch in the algae and Lv et al (2010) studied the production of lipids. Thus, it is interesting to regulate the amount of starch vs lipids that can be used of the simultaneous production of ethanol and biodiesel from algae to engineer the algae growth for the production of both (Beer et al., 2009). We assume that the dry algae consist of starch, which will produce ethanol from fermentation, lipids, that will be used for biodiesel production and protein, that will be used as cattle feed (McKendry, 2002). Thus the sum of the fractions of the three components is equal to 1. The main constrains based on the literature (Lv. et al 2010) are the following

$$
\begin{aligned}
& \text { Lipids } \leq 0.6 \text { Biomass }_{\text {dry }} \\
& \text { Protein }^{\prime} \geq 0.1 \text { Biomass }_{\text {dry }}
\end{aligned}
$$

We assume that the water that accompanies the algae after the belt can be manipulated to be the appropriate one for the fermentation process considering that this water is part of the algae, and thus not the one used for algae growing. 


\section{Transesterification:}

The oil extracted is transesterified as decribed by Severson et al (2012) using ethanol as alcohol. In that paper we identified two promising processes, the use of either alkali or enzymatic catalysts, and thus we will consider for both the integrated production of bioethanol and biodiesel. For the sake of reducing the length of the paper, we describe here only the main features of the process and we refer the reader to Severson's et al (2012) paper for the details

\section{Alkali based:}

Figure 3 shows the flowsheet for the synthesis of biodiesel using alkali catalyst. The yield to biodiesel is a function of a number of variables such as operating temperature, methanol ratio to oil, amount of catalyst. There are a number of trade-offs to obtain a high yield by adjusting the catalyst concentration, ethanol phase and working temperature. The catalyst used in reactor 2 is $\mathrm{KOH}$ because if neutralized with phosphoric acid, the product precipitates $\left(\mathrm{K}_{3} \mathrm{PO}_{4}\right)$ The model for the transesterification reaction is taken from the literature (Silva et al 2009; Joshi et al., 2010). Ttable 1 shows the range of operation of the variables.

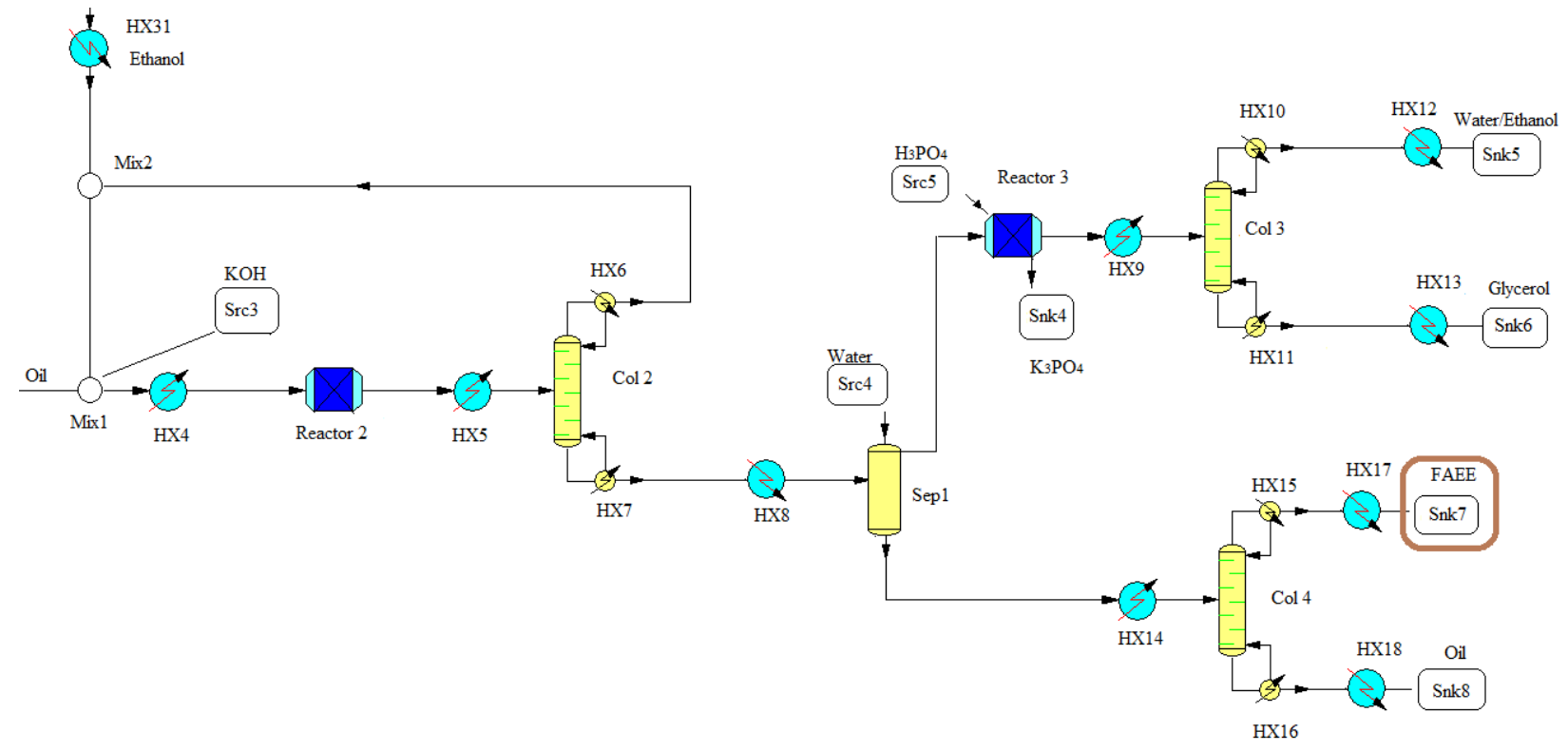

Figure 3. Flowsheet for the production of FAEE using alkali catalyst 
The predicted yield for reactor 2 is given by equation (2):

yield $=22.94293+113.88^{*}$ cata_alk $+2.828881^{*}$ Ratio_et-1.02734 ${ }^{*} \mathrm{~T}(\operatorname{Rec} 2)-1.44522{ }^{*}$ cata_alk*Ratio_et + $0.250723^{*}{ }^{*}$ ata_alk ${ }^{*}(\operatorname{Rec} 2)+\quad 0.023375^{*}$ Ratio_et $^{*} \mathrm{~T}(\operatorname{Rec} 2) \quad-41.4402^{*}$ cata_alk $^{2}-\quad 0.07568^{*}$ Ratio_et $^{2}+$ $0.006226^{*} \mathrm{~T}(\operatorname{Rec} 2)^{2}$

Table 1.-Range of operation of the variables. Alkali pretreatment

\begin{tabular}{ccc} 
Variable & Lower bound & Upper bound \\
\hline Temperature $\left({ }^{\circ} \mathrm{C}\right)$ & 25 & 80 \\
Ratio ethanol $(\mathrm{mol} / \mathrm{mol})$ & 3 & 20 \\
Catalyst & 0.5 & 1.5
\end{tabular}

The energy involved in the reaction is calculated from the experimental results in the literature, (http://www.caer.uky.edu/energeia/PDF/vol15 6.pdf). We assume the same value for both technologies. We recover the excess of ethanol in column 2 to be recycled back to the reactor. The columns are modeled using short cut methods (Biegler et al., 1997) where the operating conditions are defined to avoid thermal decomposition of glycerol. Thus the temperature at the bottoms must not exceed $150^{\circ} \mathrm{C}$, taking into account that we have a two phase mixture. We assume that at least $94 \%$ of the ethanol is recycled. The reflux ratio has to be always greater or equal to 1.2 times the minimum reflux ratio calculated using rules of thumb (Biegler et al 1997)

The bottoms are cooled down to $40^{\circ} \mathrm{C}$ in $\mathrm{HX} 8$ before phase separation (Cerboch et al., 2009). The purpose of this stage is to separate the biodiesel from the glycerol, ethanol and catalyst. Following the typical approach (West, 2008, Zhang, 2003), we assume that a water washing column is used to fully separate both phases to eliminate the ions from the catalyst with the polar phase. Phase separation is a difficult stage and there is no agreement whether gravity separation alone can do the work (Krawczyk, 1996; West, 2008). Based on experimental data from Zhou et al (2006) and Cernoch et al. (2009) we assume polar from non polar phase separation. A small amout of water, $5 \%$ of the biodiesel phase is added to the column (Cerboch et al. 2009).

The oil phase is sent to column 5 to purify the biodiesel from the unreacted oil. To avoid species decomposition, the distillate, mainly biodiesel, must exit the column below $250^{\circ} \mathrm{C}$ (Zhang et al., 2003) while the 
bottoms, mainly the remaining oil, should remain below $350-375^{\circ} \mathrm{C}$. A short cut model is used for this column assuming variable a reflux ratio from 2 to 3 (Zhang et al., 2003).

The aqueous phase is treated to remove the alkali, $\mathrm{KOH}$. We consider the use of phosphoric acid since the neutralization, see eq (3), results in $\mathrm{K}_{3} \mathrm{PO}_{4}$ that can be easily removed using a gravity separator and it can also be sold as a fertilizer.

$\mathrm{H}_{3} \mathrm{PO}_{4}+3 \mathrm{KOH} \longrightarrow \mathrm{K}_{3} \mathrm{PO}_{4}+3 \mathrm{H}_{2} \mathrm{O}$

The products of reactor 3 are calculated based on the stoichiometry of the reaction, and the final temperature is calculated assuming adiabatic operation of the reactor taking into account the heat of neutralization. Once neutralized, the stream is sent to column 3 to purify the glycerol where the bottoms, mainly glycerol, should be kept below $150^{\circ} \mathrm{C}$. Furthermore, we are interested in purities above $92 \%$ so that glycerol can be sold as a high quality product (Zhang et al., 2003). The reflux ratio is variable from 2 to 3 as well as the purity of the glycerin using 0.92 as the lower bound.

\section{Enzymatic based}

Similarly, we can use the enzymatic process, see Figure 4 for the detail of the flowsheet. According to Severson et al (2012) this process is promising in the sense that it consumes less energy and water than the one using $\mathrm{KOH}$ but its current disadvantage is the high cost of the enzymes. The model for the transesterification reactor is given by equation (3) (Rodrigues et al., 2008) and Table 2 presents the range of operation of the variables.

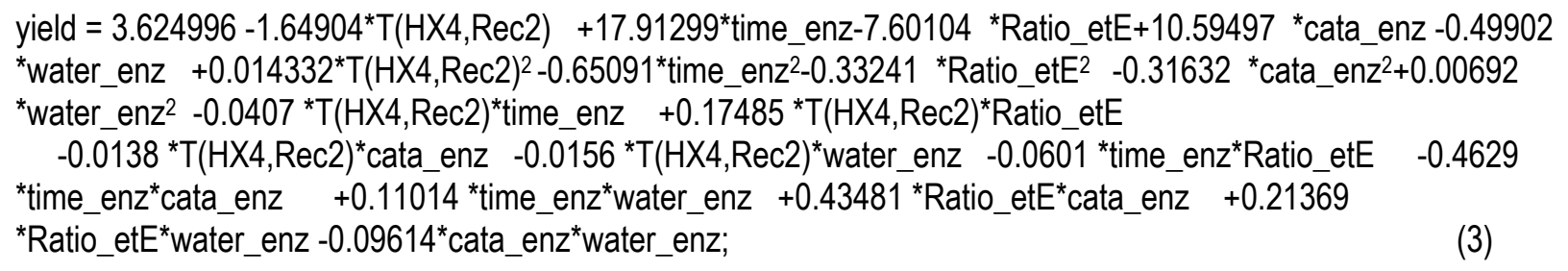




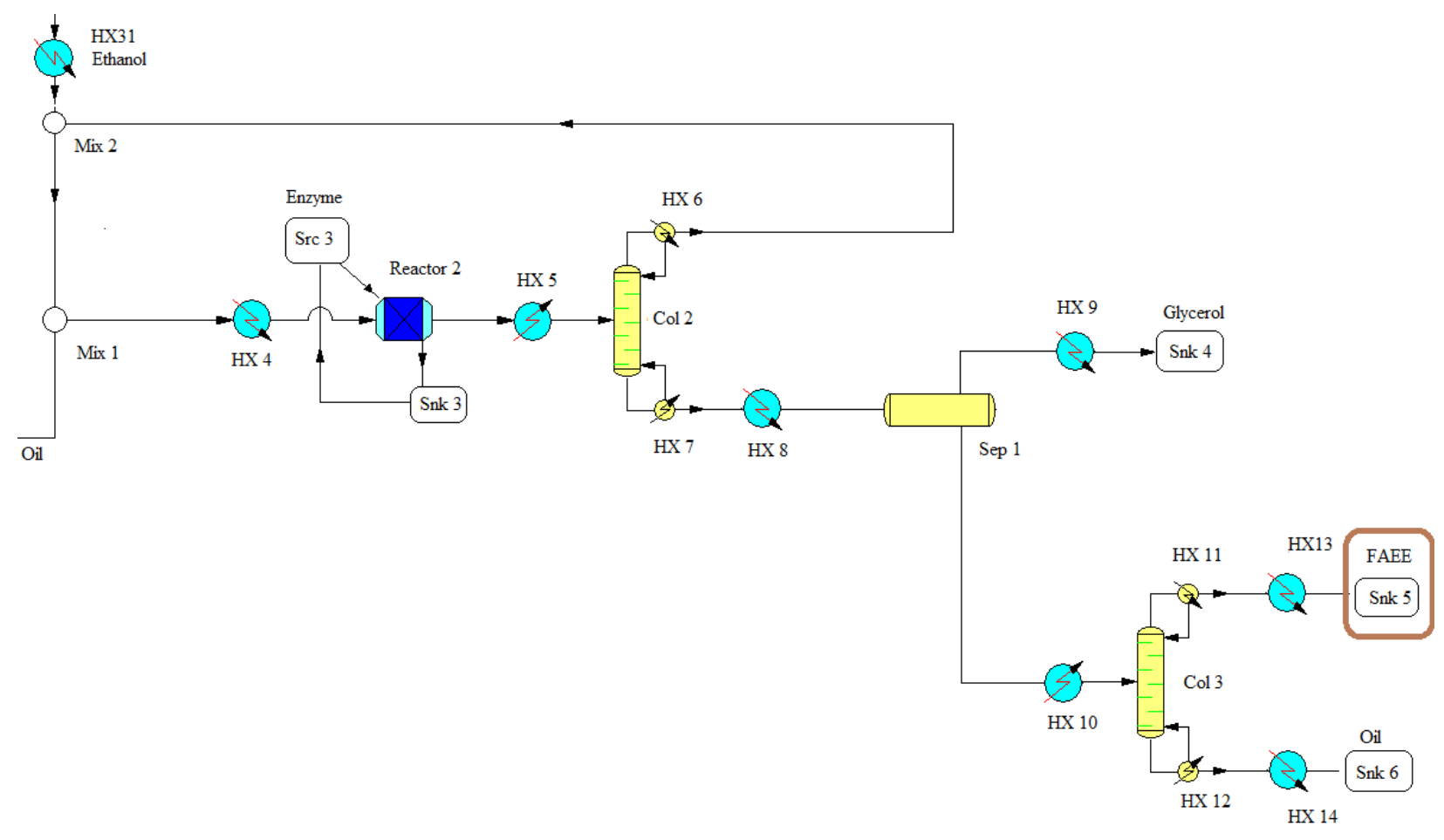

Figure 4. Flowsheet for the production of algae using enzymes

Table 2.-Range of operation of the variables for enzymatic process

\begin{tabular}{ccc} 
Variable & Lower bound & Upper bound \\
\hline Temperature $\left({ }^{\circ} \mathrm{C}\right)$ & 20 & 45 \\
Ratio ethanol $(\mathrm{mol} / \mathrm{mol})$ & 3 & 12 \\
Catalyst & 5 & 16 \\
Added water & 0 & 20 \\
Time $(\mathrm{h})$ & 6 & 13
\end{tabular}

The excess of ethanol is recovered in distillation column 2, and recycled back to the reactor, while the biodiesel is purified by means of gravimetric separation, sep1, and further distillation in col3. The main constraints related to product integrity are the same as from the previous case with the advantage that the use of supported enzymes, and thus the absence of salts, reduces the purification steps. 


\section{Ethanol production}

\section{Liquefaction and saccharification}

Liquefaction and saccharification convert the starch to fermentable sugars. This process is similar to the one used for corn ethanol as has been experimentally proved by Marsalkova et al. 2010. In this model, glucose is considered to be the only sugar. The liquefaction and saccharification operations are shown in Fig. 5. The mass coming from the oil separation stage is fed to the liquefaction tank (Liq1), where the high temperature tolerant enzyme $\alpha$-amylase is added. The $\mathrm{pH}$ range of liquefaction is $6-6.5$ and the temperature is kept at $90{ }^{\circ} \mathrm{C}$ for $30 \mathrm{~min}$ (Jacques et al.,1999; Marsalkova, et al 2010; Choil et al. 2010). The chemical reaction involved in this step is the hydrolysis of starch to maltose, which involves the use of the endoenzyme $\alpha$-amylase given by eq. (4).

$$
2\left(\mathrm{C}_{6} \mathrm{H}_{10} \mathrm{O}_{5}\right)_{n}+n \mathrm{H}_{2} \mathrm{O} \stackrel{\alpha \text {-amylase }}{\longrightarrow} n \mathrm{C}_{12} \mathrm{H}_{22} \mathrm{O}_{11}
$$

This step is followed by the use of the exoenzyme glucoamylase to achieve the conversion of maltose to glucose in the saccharification process (Sac1) given by eq. (5)

$$
\mathrm{C}_{12} \mathrm{H}_{22} \mathrm{O}_{11}+\mathrm{H}_{2} \mathrm{O} \stackrel{\text { glucoamylase }}{\longrightarrow} 2 \mathrm{C}_{6} \mathrm{H}_{12} \mathrm{O}_{6}
$$

Saccharification operates most efficiently around $65^{\circ} \mathrm{C}$ for $30 \mathrm{~min}$ (Choi et al. 2010). A heat exchanger (HX29) cools the mass coming from the liquefaction tank from $90^{\circ} \mathrm{C}$ to $65^{\circ} \mathrm{C}$. The saccharification process is carried out in a $\mathrm{pH}$ range of 5.5 for which sulfuric acid is added before the glucoamylase. For the sake of simplicity we neglect the $\mathrm{pH}$ adjustment in the process model. Furthermore, the heats of reaction to obtain glucose from starch are insignificant and thus neglected in the heat balance.

For the reactions in the liquefaction and saccharification processes, we assume a conversion efficiency of 99\% based on the amount of primary reactant (Marsalkova, 2010). The reactions are modeled on a mass basis and stoichiometric factors are used in the equations. On a mass basis, the reactions are defined by eqs. (6-7) :

$1 \mathrm{~kg}$ starch $+0.0555 \mathrm{~kg}$ water $\stackrel{\alpha \text {-amylase }}{\longrightarrow} 1.0555 \mathrm{~kg}$ maltose 
Regarding the enzymes needed in the reactions, the amount of $\alpha$-amylase to be added is $0.005 \% \mathrm{w} / \mathrm{w}$ of the biomass while the required glucoamylase is $0.1 \% \mathrm{w} / \mathrm{w}$ of the incoming mash (Choi et al, 2010) In the process model, the enzymes are treated as proteins, and hence they are added to the protein mass of the stream. The effect of the enzymes on the energy balance for both the liquefaction and saccharification units is neglected. The mass and heat balances for this section are as follows:

$W a_{\text {star }, \text { malt }}=0.0555$ is the amount of water required for hydrolyzing $1 \mathrm{~kg}$ of starch to produce maltose, while $W a_{\text {malt }, \text { gluc }}=0.0526$ is the stoichiometric water requirement for converting $1 \mathrm{~kg}$ of maltose into glucose. The terms $c o n v_{\text {star,malt }}$ and conv $v_{\text {malt,gluc }}$ stand for the conversion of starch to glucose and the conversion of glucose to maltose, respectively, and are both equal to $0.99 . E n z_{L i q}=0.00005$ is the amount of enzymes (in $\mathrm{kg}$ ) required per $\mathrm{kg}$ of corn mash liquefied, while $E n z_{S a c}=0.001$ is the amount of enzymes (in $\mathrm{kg}$ ) required in the saccharification tank per kg of corn slurry saccharified.

Hydrolysis

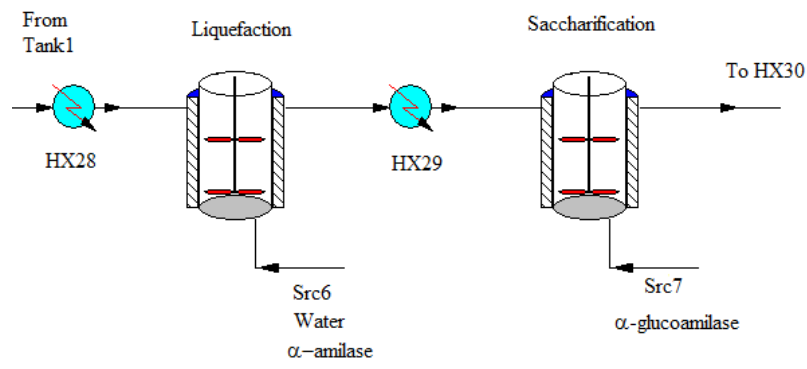

Figure 5.- Flowsheet for hydrolysis 


\section{Fermentation and solid separation.}

The next step in the production of bioethanol is the fermentation of the slurry. We need to cool down the stream, using heat exchanger $H X 30$ and then into the fermentor where yeast, urea are added as well as extra water in case is necessary. The temperature of the slurry entering the fermentor must be $38^{\circ} \mathrm{C}$.

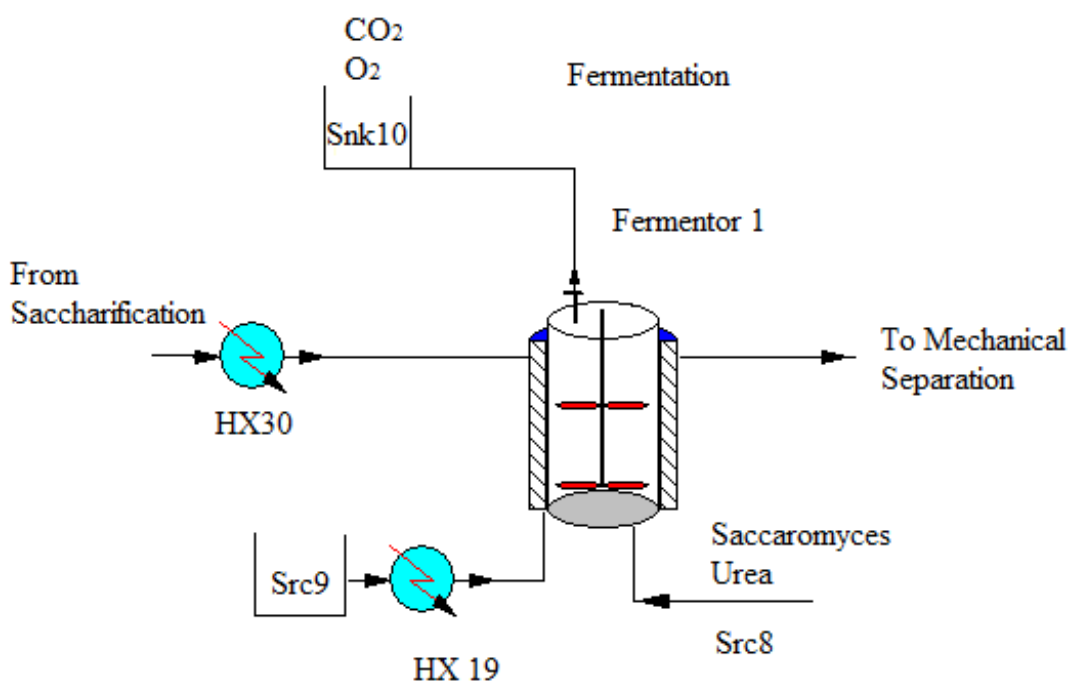

Figure 6.-Detail of flowsheet for fementor.

The fermentation process is batch, and thus storage tanks will be needed to maintain continuous operation of the upstream and downstream processes. Both are considered for the economic evaluation but not described in terms of process modelling. Moreover, the production capacity may result in the need of a train of parallel fermentors. In terms of mass and energy balances we assume a single fermentor, but for costing purposes we will determine the number of fermentors we need for the production capacity. The operations in this part of the flowsheet appear in Fig. 6. The loading and unloading of the fermentor are assumed to be instantaneous in the model.

In the fermentor, yeast of the type Saccharomyces cerevisiae is used to convert glucose into ethanol. The most often used form is active dry yeast. The amount of yeast used in the fermentor is a function of the amount of corn feed $\left(2.765 \times 10^{-4} \mathrm{~kg}\right.$ yeast per $\mathrm{kg}$ corn feed processed). The fermentation is assumed to be carried out for a maximum total time of $30 \mathrm{~h}$. During this time, the first $4 \mathrm{~h}$ are what is known as a lag phase (t_lag), when the 
incubation of yeast takes place, and hence there is no conversion of glucose to ethanol. In the remaining $26 \mathrm{~h}$ (t_fer_max), all the glucose gets converted into ethanol and a number of unavoidable by-products. The time dependence of the fermentation reaction will assume a linear conversion of glucose starting after the initial lag phase of $4 \mathrm{~h}$. The total time (or the cycle time) in the fermentor is then given by:

$$
t \_c y c=t \_l a g+t \_f e r
$$

where the actual fermentation time, $t \_f e r(h)$, and is a decision variable.

There are a number of reactions taking place in the fermentor, see eq (9). Table 3 shows the conversions of those reactions

1. Glucose to ethanol: $\mathrm{C}_{6} \mathrm{H}_{12} \mathrm{O}_{6} \stackrel{\text { yeast }}{\longrightarrow} 2 \mathrm{C}_{2} \mathrm{H}_{6} \mathrm{O}+2 \mathrm{CO}_{2} \quad \Delta \mathrm{H}=-84.394 \mathrm{~kJ} / \mathrm{mol}$

2. Glucose to glycerol: $\mathrm{C}_{6} \mathrm{H}_{12} \mathrm{O}_{6}+2 \mathrm{H}_{2} \mathrm{O} \stackrel{\text { yeast }}{\longrightarrow} 2 \mathrm{C}_{3} \mathrm{H}_{8} \mathrm{O}_{3}+\mathrm{O}_{2}$

3. Glucose to succinic acid: $\mathrm{C}_{6} \mathrm{H}_{12} \mathrm{O}_{6}+2 \mathrm{CO}_{2} \stackrel{\text { yeast }}{\longrightarrow} 2 \mathrm{C}_{4} \mathrm{H}_{6} \mathrm{O}_{4}+\mathrm{O}_{2}$

4. Glucose to acetic acid: $\mathrm{C}_{6} \mathrm{H}_{12} \mathrm{O}_{6} \stackrel{\text { yeast }}{\longrightarrow} 3 \mathrm{C}_{2} \mathrm{H}_{4} \mathrm{O}_{2}$

5. Glucose to lactic acid: $\mathrm{C}_{6} \mathrm{H}_{12} \mathrm{O}_{6} \stackrel{\text { yeast }}{\longrightarrow} 2 \mathrm{C}_{3} \mathrm{H}_{6} \mathrm{O}_{3}$

6. Glucose to cell mass $\mathrm{C}_{6} \mathrm{H}_{12} \mathrm{O}_{6}+1.2 \mathrm{NH}_{3} \stackrel{\text { yeast }}{\longrightarrow} 6 \mathrm{CH}_{1.8} \mathrm{O}_{0.5} \mathrm{~N}_{0.2}+2.4 \mathrm{H}_{2} 0+0.3 \mathrm{O}_{2}$

Table 3.- Chemical reactions in fermentor

\begin{tabular}{|c|c|}
\hline Reaction & Conversion \\
\hline glucose $\stackrel{\text { yeast }}{\longrightarrow} 2$ ethanol +2 carbon dioxide & 0.92 \\
\hline $\mathrm{C}_{6} \mathrm{H}_{12} \mathrm{O}_{6}+2 \mathrm{H}_{2} 0 \stackrel{\text { yeast }}{\longrightarrow} 2 \mathrm{C}_{3} \mathrm{H}_{8} \mathrm{O}_{3}+\mathrm{O}_{2}$ & 0.034 \\
\hline $\mathrm{C}_{6} \mathrm{H}_{12} \mathrm{O}_{6}+2 \mathrm{CO}_{2} \stackrel{\text { yeast }}{\longrightarrow} 2 \mathrm{C}_{4} \mathrm{H}_{6} \mathrm{O}_{4}+\mathrm{O}_{2}$ & 0.01 \\
\hline glucose $\stackrel{\text { yeast }}{\longrightarrow} 2$ lactic acid & 0.002 \\
\hline glucose $\stackrel{\text { yeast }}{\longrightarrow} 3$ acetic acid & 0.0024 \\
\hline glucose +1.2 ammonia $\stackrel{\text { veast }}{\longrightarrow} 6$ cell mass +2.4 water +0.3 oxygen & 0.0316 \\
\hline
\end{tabular}


In the last reaction of Table 3, ammonia is one of the reactants. This reaction is indicative of the anaerobic growth of the yeast, where the cell mass of the yeast is increased. The ammonia comes from the following reaction that is also assumed to take place inside the fermentor., eq. (10)

urea + water $\stackrel{\text { urease }}{\longrightarrow} 2$ ammonia + carbon dioxide

$\mathrm{CO}\left(\mathrm{NH}_{2}\right)_{2}+\mathrm{H}_{2} \mathrm{O} \stackrel{\text { urease }}{\longrightarrow} 2 \mathrm{NH}_{3}+\mathrm{CO}_{2}$

The urea that is required for the reaction is fed into through the source Src7, from where it goes into the storage tank Str1 and finally to the fermentor Fer1. In order to avoid nitrogen limited growth, we assume that we can feed $10 \%$ more urea than what is stoichiometrically required in the fermentor. Besides sugar and nitrogen, other nutrients such as oxygen, and minerals and vitamins are also necessary for efficient fermentation of glucose to ethanol, although in the model the effect of these nutrients is neglected.

\section{Ethanol purification.}

Once the liquid stream is separated from the one with solids, we recover the protein by flotation (Karuppiah et al., 2008) which can be used for cattle feed, see Figure 7. Next, the ethanol must be dehydrated to fuel grade.

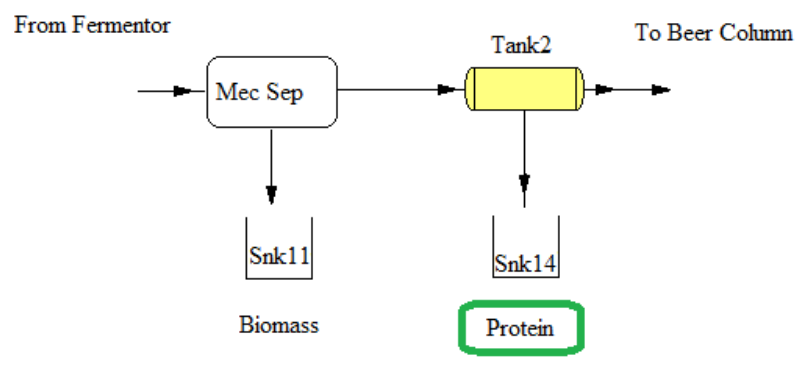

Figure 7.- Protein recovery

Beer column.

Figure 8 shows the scheme of the distillation column. This column is in fact a multieffect column (Columns 5-7) due to the large energy and water savings reported in previous work (Karuppiah et al. 2008, Ahmetovic et al 
2010). The characteristic feature is that the columns operate at different pressures and with different flow rates so that the reboiler of the low pressure column acts as the condenser of the higher pressure column integrating the heat. The relative volatility of ethanol with respect to water is taken to be 2.24 and is assumed to be constant over the temperature range of the column. Since the two main components of the feed are ethanol and water we neglect the effect of the other small components such as different acids and glycerol. Therefore, water is chosen to be the heavy key and ethanol the light key for the calculations in both the beer column as well as in the rectification column. The components in small quantities are heavier than water and are assumed to exit through the bottoms. However, due to the small amount we neglect its effect on the vapor - liquid equilibrium. A partial condenser is used in the beer column to obtain a vapor distillate since the molecular sieves handle vapor mixtures of ethanol and water. Since a partial condenser is used in the beer column, the composition of the condensed liquid is not the same as the top product, which is removed as saturated vapor. It is assumed that the extracted vapor is in equilibrium with the condensed phase. The composition of the refluxed stream can be calculated by using the vapor-liquid equilibrium relationship for water and ethanol at the temperature of the condenser. The heat loads in the reboiler and the condenser depend on the reflux ratio also, since the recovery of ethanol at the top is fixed at $99.6 \%$, the bottom stream contains almost no ethanol. Thus, only water and ethanol will pass to the final dehydration step. A pressure drop of $10 \%$ the operating pressure is assumed for each of the columns. The temperature is calculated as well as the optimal removal of water while the recovery of ethanol is fixed to be 0.996 . With this and the relative volatility we calculate the number of trays of the column. The temperatures of the inlet and outlet streams are calculated based on bubble and dew point calculations, Biegler et al. (1997). We consider a partial condenser and the reflux ratio is taken to be $\left(R_{B C 1}\right)$ of 1.5 according to the results by Karuppiah et al. (2008). 


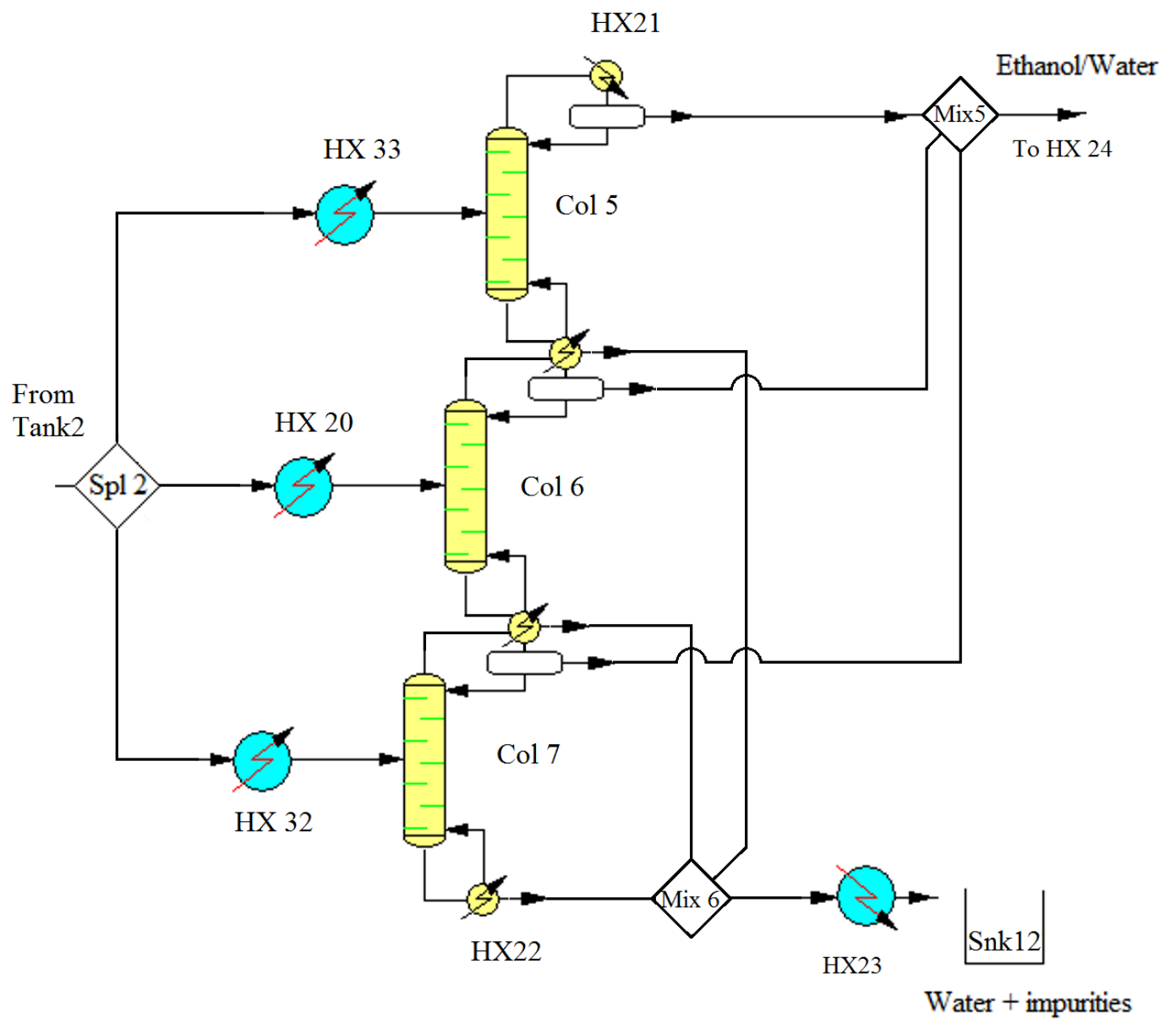

Figure 8. Multieffect Beer column

\section{Ethanol dehydratation}

For the final dehydration of the ethanol we use molecular sieves ( Martin \& Grossmann, 2011b) see figure 9. There is a lower bound on the fraction of ethanol entering the molecular sieve (0.8). Adsorption takes place at $95^{\circ} \mathrm{C}$. Heat exchanger $H X 24$ heats the inlet stream from the mixer Mix 5 up to $95{ }^{\circ} \mathrm{C}$. The molecular sieve is a bed of zeolite that operates in semi-continuous mode similar to the cycle described for the corn grit absorbers. The bed is saturated with water after a period of time and is then regenerated. Hence, there are usually two sieves being operated in parallel - one being saturated with water (MS1) while the other (MS1) is being regenerated (or dehydrated) using air under vacuum. Heat exchanger $H X 25$ heats air with an assumed relative humidity of $70 \%$ at $20{ }^{\circ} \mathrm{C}$ to $95{ }^{\circ} \mathrm{C}$. The air at the outlet of the dehydrating molecular sieve is cooled down to $25^{\circ} \mathrm{C}$ in heat exchanger 
$H X 26$, and this stream leaves this exchanger saturated with water at $25{ }^{\circ} \mathrm{C}$. The data used in the model for the molecular sieves s taken from Jacques et al. (1999) and is summarized in Table 4.

Table 4. Data for molecular sieves

\begin{tabular}{|c|c|}
\hline Parameter & Value \\
\hline$x_{\text {in,MS }}^{\text {ethanolmin }}$ & 0.8 \\
\hline $\begin{array}{c}a d s_{-} \text {potential } \\
\text { (kg water } / \mathrm{kg} \\
\text { adsorbent) }\end{array}$ & 0.08 \\
\hline$t_{-} M S_{\text {saturation }}(\mathrm{s})$ & 360 \\
\hline$r h_{\text {in,MS }}$ (\%) & 70 \\
\hline$r h_{\text {out }, M S}$ (\%) & 70 \\
\hline
\end{tabular}

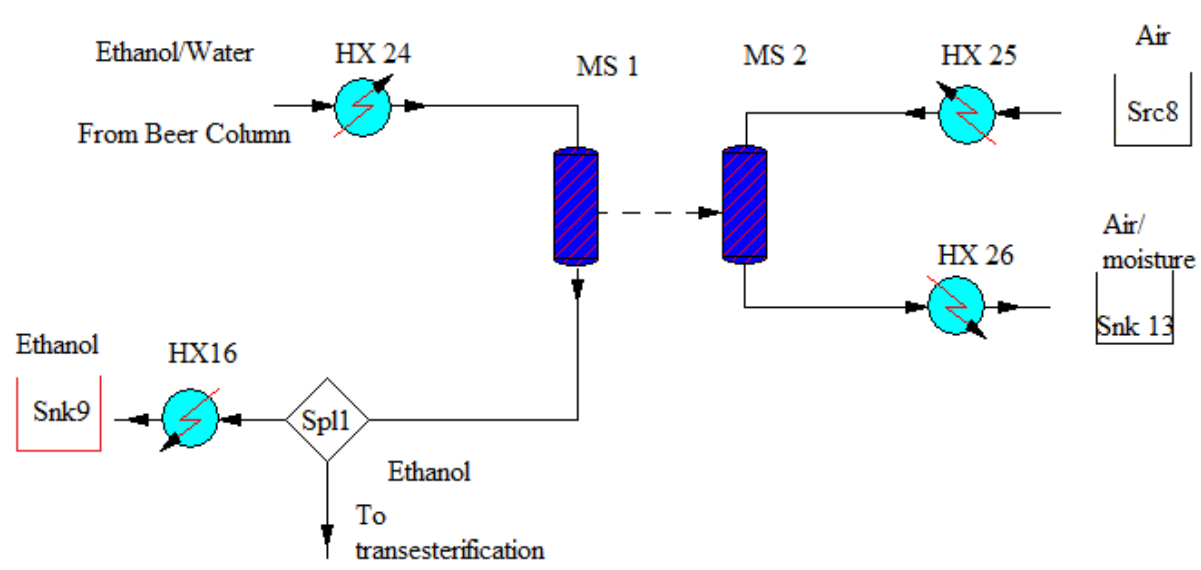

Figure 9.- Ethanol dehydration

Ethanol production and recycle

The transesterifcation operates at 2 to 4 bar. We condense the ethanol coming from the molecular sieves and we mixed it with the recycled one in order to provide the ethanol for the production of biodiesel, see Figure 10. 


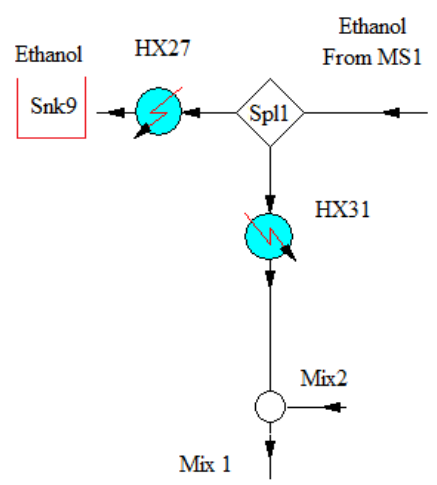

Figure 10.- Ethanol split to product of to biodiesel production

\section{Objective function}

The objective function is a simplified profit involving income from the production of biodiesel, bioethanol as well as byproducts such as glycerol, protein and fertilizer and the consumption of different chemicals, catalysts and energy (steam), see Table 5 for the data. Since we simultaneously optimize and heat integrate the flowsheet, in the objective function we include QS_max which accounts for the optimal heat integration(Biegler et al 1997). Each problem consists of around 3500 equations and 4100 variables.

$$
\begin{aligned}
& \mathrm{Z}=C_{F A M E} * \mathrm{fc}(\mathrm{FAEE})+C_{\text {Glycerol }} * \mathrm{fc}(\mathrm{Glycerol})-C_{\text {Steam }} *(1 / \lambda) *\left(\mathrm{QS} \_ \text {max }\right)-C_{\text {enzy }} * \text { Enzymeadded } * \mathrm{f}_{\text {recylce }} \\
& +C_{E t O H} * \mathrm{fc}(\mathrm{EtOH})+\mathrm{C}_{\text {Protein }} * \mathrm{fc}(\text { Protein }) \\
& \mathrm{Z}=C_{F A M E} * \mathrm{fc}(\mathrm{FAEE})+C_{\text {Glycerol }} * \mathrm{fc}(\mathrm{Glycerol})+C_{K_{3} P O_{4}} * \mathrm{fc}(\mathrm{K} 3 \mathrm{PO} 4)-C_{\text {Steam }} *(1 / \lambda) *\left(\mathrm{QS} \_ \text {max }\right)-C_{K O H} * \mathrm{fc}(\mathrm{KOH}) \\
& +C_{E t O H} * \mathrm{fc}(\mathrm{EtOH})-C_{\mathrm{H}_{3} P O_{4}} * \mathrm{fc}(\mathrm{H} 3 \mathrm{PO} 4)+\mathrm{C}_{\text {Protein }} * \mathrm{fc}(\text { Protein }) ;
\end{aligned}
$$

Table 5.- Chemicals cost

\begin{tabular}{lcl} 
Chemical & Price $(\$ / \mathrm{kg})$ & Source \\
\hline Fertilizer & $0.367^{*}$ & http://www.crystalsugar.com/agronomy/agtools/npk/Default.aspx, \\
Enzyme & 0.7 & Sotof. Et al 2010 \\
$\mathrm{KOH}$ & 1.6 & $\underline{\text { http://www.echinachem.com/en/products/Product.aspx?SUpplyOrRequestID=578325 }}$ \\
$\mathrm{H}_{3} \mathrm{PO}_{4}$ & 0.34 & West et al 2008, \\
Glycerin & 0.3 & Crude 2011. http://www.icispricing.com/il_shared/Samples/SubPage170.asp \\
Hexane & 0.41 & Zhang et al 2003 \\
Protein & 0.2 & USDA 2011 www.extension.iastate.edu/agdm \\
$\mathrm{K}_{3} \mathrm{PO}_{4}$ & 1.9 & http://www.sunivo.com/ennew/Products/Products_list.asp?sProdKw=potassium phosphate \\
\hline
\end{tabular}

$\left.{ }^{*}\right)$ Mean value of a number of fertilizers 
In order to decide among the alternatives (two transesterification technologies) and to engineering the algae growth, a detailed cost analysis is performed after the optimization involving raw material cost, maintenance, cost of utilities and chemicals, labor, annualized equipment cost and the cost for the management of the facility, following Sinnot's ${ }^{51}$ method;see also previous papers by the authors ${ }^{17}$ for further details. The prices for facilities are updated from the literature $\left(0.019 \$ / \mathrm{kg} \mathrm{Steam}^{52} ; 0.057 \$ /\right.$ ton cooling water $\left.{ }^{52}, 0.06 \$ / \mathrm{kWh}^{53} 0.021 \$ / \mathrm{kg} \mathrm{Oxygen}^{54}\right) .0 .06 \$ / \mathrm{kWh}$ (Balat et al. 2008), 4.876 \$MMBTU for natural gas http://www.wtrg.com/daily/gasprice.html. Finally, the cost correlations for the different equipment can be found in the supplementary material of Martin and Grossmann (2011) and Martin \& Grossmann 2012. In a production plant $0.083 \mathrm{kwh}$ of electricity are used per gallon of biodiesel (Radich, 2010) . Finally, the model by Ahmetovic and Grossmann (2011) is used in order to design the optimal water network so as to be able to fully compare this integrated process using ethanol with the stand alone process (Martín \& Grossmann, 2011)

\section{RESULTS}

The idea is to engineer the algae composition to drive the growing for the simultaneous production of ethanol and biodiesel including other byproducts such as glycerol and protein. The prices presented in Table 5 are the ones used. We assume $\$ 1 / \mathrm{kg}$ of biofuels, biodiesel and bioethanol. Of particular interest is the price of the byproducts of the process, either the protein and the glycerol, whose price is responsible for the final decision on the algae composition. Table 6 presents the distribution of the products and the optimal algae growth to be design. Biodiesel is the main product of the facility with more that $90 \%$ of the total biofuel production. Glycerol is a valuable byproduct whose economics will determine the profitability of the plant as well as the use of protein. In both designs the same algae composition is found $60 \%$ oil, $30 \%$ Starch and $10 \%$ protein in the dry biomass produced. 
Table 6.- Algae composition and optimal product distribution

\begin{tabular}{cccccc} 
Alkali & \multicolumn{5}{c}{ Enzymatic } \\
& $\mathrm{Kg} / \mathrm{s}$ & & & $\mathrm{Kg} / \mathrm{s}$ & \\
EtOH & 0,748 & & EtOH & 0,866 & \\
Biodiesel & 8,555 & & Biodiesel & 8,353 & \\
Prot & 1,431 & & Prot & 1,43 & \\
Glycerol & 0,890 & & Glycerol & 0,869 & \\
& & & & & \\
Algae mass & 15 & $\% \mathrm{w} / \mathrm{w}$ & Algae mass & 15 & $\% \mathrm{w} / \mathrm{w}$ \\
Oil & 9 & 60 & Oil & 9 & 60 \\
Star & 4,5 & 30 & Star & 4,5 & 30 \\
Prot & 1,5 & 10 & Prot & 1,5 & 10
\end{tabular}

In Table 7 we present the optimal operating conditions of the multieffect columns, very similar y both cases which also validate the sequential approach used in previous papers by the authors for the dehydration of the ethanol produced either by sugars or syngas fermentation (Martín \& Grossmann, 2011a\&b). The main point here is that the operating conditions allow better energy integration with the whole plant since the condenser of the multieffect column can be used to provide energy to other units, while the reboiler will reduce the need for cooling at the same time as the steam consumption is reduced.

Table 7.- Summary of the operating condition of the distillation multieffect columns

\begin{tabular}{lcccccc}
\hline & Column & $\alpha$ & $\beta$ & $\mathrm{P}(\mathrm{LP}) \mathrm{mmHg}$ & LP/IP & IP/HP \\
\hline Alkali & Col5-7 & 0.084 & 0.238 & 195 & 2.13 & 2.04 \\
\hline Enzymatic & Col5-7 & 0.084 & 0.238 & 275 & 2.36 & 2.77 \\
\hline & Legend: LP: Low pressure: IP: Intermediate pressure: HP: High pressure & \\
& $\alpha:$ fraction of total feed to LP column & $\beta$ : fraction of total feed to IP column & \\
&
\end{tabular}




\section{DISCUSSION AND WATER CONSUMPTION}

The cost correlations used can be found in the supplementary material of previous papers by the authors (Martin \& Grossmann, 2011 A\& B; Martin \& Grossmann 2012). The first comparison we want to establish is between the optimal result at the transesterification reactor for the production of biodiesel alone (Severson et al, 2012) and this integrated flowsheet. Table 8 shows the results. There is no difference in the case of the alkali catalyzed one while a slight difference in the operating conditions in the case of the enzymatic reactor can be seen. The operating temperature is lower in the integrated design and the ethanol ratio in the reactor is half the value in order to improve the energy integration with the rest of the process. The biodiesel production is endothermic requiring energy. If we have to provide that energy at $30^{\circ} \mathrm{C}$ more equipment will be able to provide it. In terms of the ethanol ratio that determines the energy at the ethanol recovery column and also the temperature.

Table 8.- Optimal operating conditions

\begin{tabular}{|c|c|c|c|c|}
\hline & \multicolumn{2}{|l|}{ Alkali cat } & \multicolumn{2}{|c|}{ Enzymatic } \\
\hline & $\begin{array}{c}\text { Alone }\left(^{*}\right) \\
\text { (ethanol } \$ 1 / g a l)\end{array}$ & Integrated & $\begin{array}{c}\text { Alone }\left(^{*}\right) \\
\text { (ethanol } \$ 1 / g a l)\end{array}$ & Integrated \\
\hline Temperature $\left({ }^{\circ} \mathrm{C}\right)$ & 75 & 75 & 45 & 30 \\
\hline Pressure(bar) & $4^{f}$ & $4^{f}$ & $4^{f}$ & $4^{f}$ \\
\hline ratio_et (mol/mol) & 5.7 & 5.7 & 8.9 & 4.1 \\
\hline Time (h) & 0.5 & 0.5 & 6.9 & 8.0 \\
\hline Cat/lipase(\%w/w) & 1.5 & 1.5 & 14.0 & 13.0 \\
\hline Water added (\%w/w) & - & & 0.0 & 0.0 \\
\hline
\end{tabular}

f fixed condition in the experimental data $\left(^{*}\right)$ Kristen et al 2012 


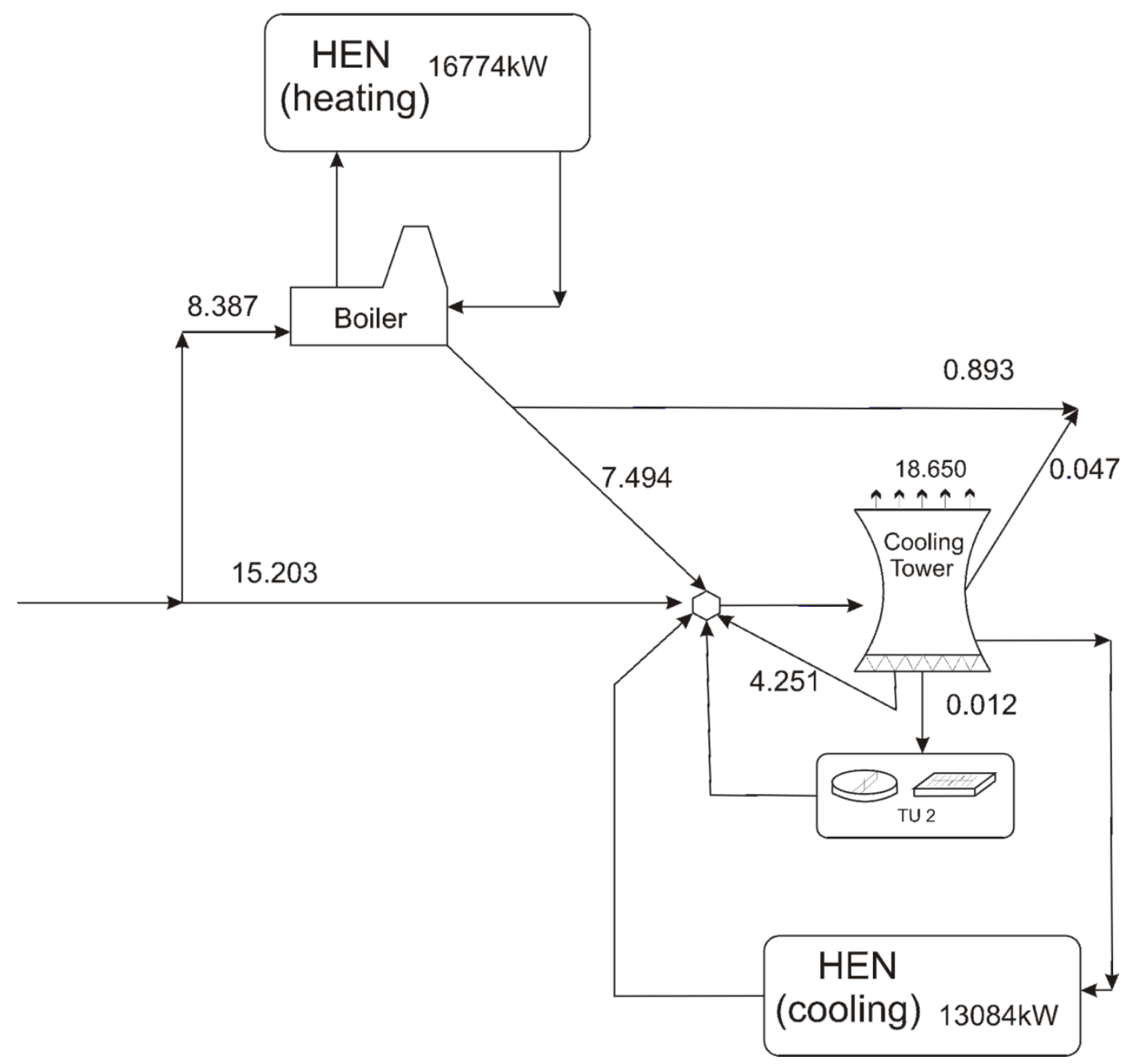

Figure 11.- Freshwater network. Enzymatic case. Flows in (t/h)

The water consumption is calculated considering the consumption in the cooling tower and the boiler, as well as the amount used in the washing stage of the biodiesel production. We use the model for water network design in the same way as in Ahmetovic et al. (2010), Martín et al. (2010) based on the model by Ahmetovic \& Grossmann (2011) where further information of the models of the utility system design can be found. Figure 11 shows the water network for the enzymatic case. We assume that the water used in the ponds is not fresh, and thus the evaporation losses are not considered for the freshwater balance. We also assume that the water accompanying the cells can be used in the hydrolysis and fermentation. However, in order to minimize the ponds water consumption, there will be a closed cycle with the water coming from the distillation column, which is treated using 
secondary and biological treatment and recycled back to the ponds. Figure 12 shows the partial water network for the enzymatic example.

Table 9 summarizes the production cost, the energy consumption and the water consumption. As it can be seen the enzymatic path is almost as expensive as the alkali one, but it is more environmental friendly due to the lower energy and water consumption. This fact is inherited from the production of biodiesel alone (Severson et al. 2012) where the cost of the enzyme make biodiesel production more expensive but the energy and water consumption were lower. Figure 13 shows the distribution of the cost that justifies the slightly lower cost using the alkali path. Mainly the chemicals such as the fertilizers generated in the alkali path, the protein and the glycerol together with and the lower cost of the catalysts ( $\mathrm{KOH}$ vs. Enzyme) provides an advantage for this option.

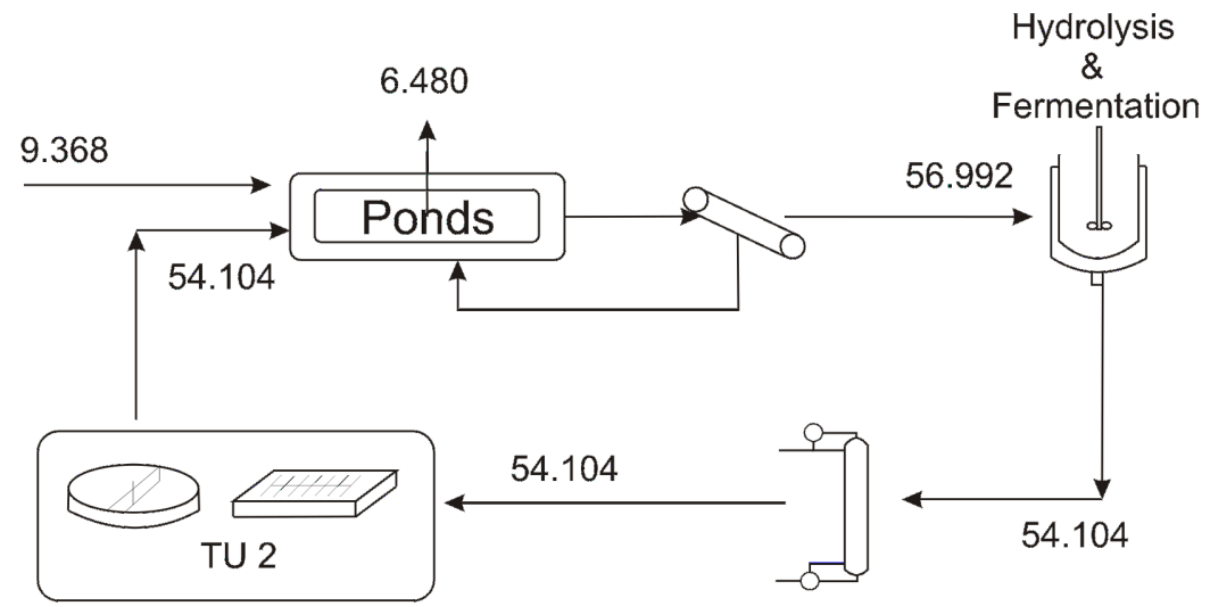

Figure 12.- Non fresh water recycle. Enzymatic synthesis. Flows in (t/h)

Table 9.-Summary of results

\begin{tabular}{ccc} 
& Alkali cat & Enzymatic \\
\hline \$/gal $\left.\right|_{\text {biofuel }}$ & 0.32 & 0.35 \\
\hline Energy (MJ/gal $\left.\left.\right|_{\text {biofuel }}\right)$ & 6.90 & 4.20 \\
\hline Water (gal/gal $\left.\left.\right|_{\text {biofuel }}\right)$ & 0.81 & 0.61 \\
\hline Investment (MM\$) & 177 & 178 \\
\hline Capacity (Mgal/yr) & 91 & 90 \\
\hline
\end{tabular}




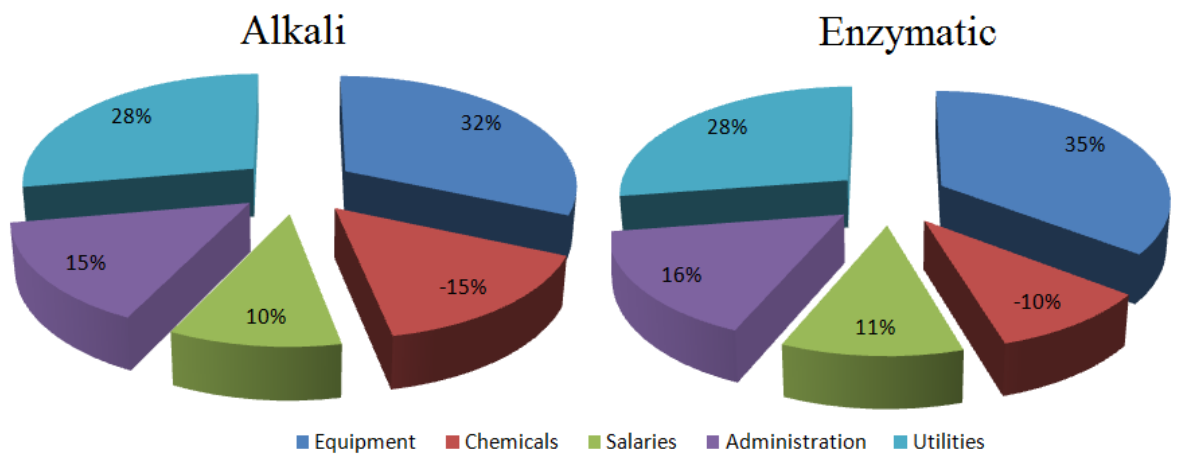

Figure 13.- Production cost distribution

Thus, process integration reduces the production cost of the biofuels and, due to the fact that biodiesel is the most abundant product, $90 \%$ of the total amount of biofuels, the plant requires energy and the water consumption is low inheriting these characteristics from the biodiesel production plants (Martín \& Grossmann 2011, Severson et al. 2012). The enzymatic process is promising, mainly in terms of energy and water consumption compared to the alkali one, but the high cost of the enzyme reduces its profitability. Comparing this process with the production of bioethanol using methanol (Martín and Grossmann, 2011) the integrated process is competitive in terms of production cost and water consumption ( $\$ 0.47 / \mathrm{gal}, 0.60 \mathrm{gal} / \mathrm{gal}$ and $1.94 \mathrm{MJ} / \mathrm{gal}$ for the use of methanol) but it requires more energy due to the pretreatment that the starch needs to access the glucose for fermentation and the dehydration stages for the ethanol.

The investment cost of the processes is $177 \mathrm{MM} \$$ and $178 \mathrm{MM} \$$ for the alkali and the enzymatic one for producing 91 and 86 million gallons a year of biofuel respectively, $90 \%$ corresponding to biodiesel. These values are comparatively higher than the production of biodiesel alone (Martín \& Grossmann, 2011) but in the range of the production of bioethanol from hydrolysis for a lower production capacity, usually limited by the availability of raw material to $60 \mathrm{MMgal}$ year, as well as bellow the ones for bioethanol (335\$MM) or FT-diesel (212MM\$) production from gasification of switchgrass also for $60 \mathrm{MMgal} / \mathrm{yr}$ (Martin \& Grossmann, 2011).

\section{CONCLUSIONS}

We have analyzed two paths, alkali or enzymatic catalyzed, for the simultaneous production of bioethanol and biodiesel from algae to engineer the algae composition towards the optimal distribution of products. We propose 
the integrated production including algae growing, oil transesterification, ethanol recovery and biodiesel purification, and starch treatment, fermentation and ethanol dehydration by means of multieffect columns and molecular sieves with simultaneous optimization and heat integration.

The optimal algae composition in dry matter corresponds to $60 \%$ oil, $30 \%$ starch and $10 \%$ protein no matter which production path is selected. However, we acknowledge that it may depend on the product and byproduct prices (glycerol and protein). Among the two alternatives for biodiesel production both are similar in terms of production cost, but the enzymatic catalyzed one requires less energy and water $(4.20 \mathrm{MJ} / \mathrm{gal} \& 0.61 \mathrm{gal} / \mathrm{gal}$ respectively) and thus is the process of choice.

Even though the integrated process increases the energy and water consumption, the simultaneous production of ethanol and biodiesel is more advantageous than the production of biodiesel using ethanol alone since it reduces the biofuel production cost around $20 \%$.

\section{References}

Ahmetović, E., Martin, M., Grossmann, I. E. (2010) Optimization of Energy and Water Consumption in Corn-based Ethanol Plants. Ind. Eng. Chem. Res. 49 (17), pp 7972-7982

Balat, M.; Balat, H.; Öz, C. (2008) Progress in bioethanol processing Progress in Energy and Combustion Science, 34,5 , Pages 551-573

Laura L Beer, Eric S Boyd, John W Peters and Matthew C Posewitz (2009) Engineering algae for biohydrogen and biofuel production Current Opinion in Biotechnology 2009, 20:264-271

Biegler, L.T.; Grossmann, I. E.; Westerberg, A. W. (1997) Systematic Methods of Chemical Process Design", Prentice Hall, New Jersey.

Borowitzka, M.A., 2005. Culturing microalgae in outdoor ponds. In: Andersen, R. (Ed.), Algal Culturing Techniques. Academic Press, New York, pp. 205-217.

Brennan, L., Owende, P., 2010. Biofuels from microalgae-a review of technologies for production, processing, and extractions of biofuels and co-products. Renew. Sustain. Energy Rev. 14, 557-577.

Brown, L. M. \& K. G. Zeiler. 1993. Aquatic Biomass and Carbon Dioxide Trapping. Energy Conversion Management (34):1005-1013

Chen, P., Min, M., Chen, Y., Wang, L., Li, Y., Chen, Q., Wang, C., Wan, Y., Wang, X., Cheng, Y., Deng, S., Hennessy, K., Lin, X., Liu, Y., Wang, Y., Martinez, B., Ruan, R., 2009. Review of the biological and engineering aspects of algae to fuels approach. Int. J. Agric. Biol. Eng. 2, 1-30. 
Chiaramonti, D., 2007. Bioethanol: role and production technologies. In: Ranalli, P. (Ed.), Improvement of Crop Plants for Industrial End Uses, pp. 209-251.

Seung Phill Choi, Minh Thu Nguyen, Sang Jun Sim (2010) Enzymatic pretreatment of Chlamydomonas reinhardtii biomass for ethanol production Bioresource Technology, 101, 5330-5336

Michal Cernoch, František Skopal and Martin Hájek Separation of reaction mixture after ethanolysis of rapeseed oil Eur. J. Lipid Sci. Technol. 2009, 111, 663-668 (separation)

Dimian, A.C., Sorin, C (2008) Chemical Process Desing. Computer - Aided Case Studies. Wiley-VCH. Weinheim

Giuliano Dragone, Bruno D. Fernandes, Ana P. Abreu, António A. Vicente, José A. Teixeira (2011) Nutrient limitation as a strategy for increasing starch accumulation in microalgae. Applied Energy. doi:10.1016/j.apenergy.2011.03.012

Donner, S.D., Kucharik, C.J., 2008. Corn-based ethanol production compromises goal of reducing nitrogen export by the Mississippi River. Proc. Natl. Acad. Sci. USA 105, 4513-4518.

Duran, M.A., Grossmann, I.E (1986) Simultaneous optimization and heat integration of chemical processes. AIChE, J., 32, 123-138

Fargione, J., Hill, J., Tilman, D., Polasky, S., Hawthorne, P., 2008. Land clearing and the biofuel carbon debt. Science 319, 1235-1238.

Franceschin, G.; Zamboni, A.; Bezzo, F.; Bertucco, A. (2008) Ethanol from corn: a technical and economical assessment based on different scenarios Chem.Eng. Res. Des., 86, 5, 488-498

Gregg, D., Saddler, J.N. (1995) Bioconversion of lignocellulosic residue to ethanol: Process flowsheet development. Biomass Bioener., 9, 1-5, 287-302

Harun, R., Danquah, M.K., Forde, G.M., 2010. Microalgal biomass as a fermentation feedstock for bioethanol production. J. Chem. Technol. Biotechnol. 85, 199-203.

Harun, R., Danquah, M.K. (2011) Enzymatic hydrolysis of microalgal biomass for bioethanol production Chemical Engineering Journal 168, 1079-1084

Huntley, M., Redalje, D.G., 2007. CO2 mitigation and renewable oil from photosynthetic microbes: a new appraisal. Mitigat. Adapt. Strat. Global Change 12, 573-608

John, R.P., Anisha, G.S., Nampothiri, K. M., Pandey., A. (2011) Micro and macroalgal biomass: A renewable source for bioethanol Bioresource Technology 102 (2011) 186-193

Johnson, M.B., Wen, Z., 2009. Production of biodiesel fuel from the microalga Schizochytrium limacinum by direct transesterification of algal biomass. Energy Fuel 23, 5179-5183

Jacques, K.; Lyons, T. P.; Kelsall, D. R. (1999) "The Alcohol Textbook”, $3^{\text {rd }}$ ed., Nottingham University Press., United Kingdom.

Hem Chandra Joshi; Joe Toler; Terry Walker Optimization of Cottonseed Oil Ethanolysis to Produce Biodiesel High in Gossypol Content J Am Oil Chem Soc DOI 10.1007/s11746-008-1200-7 (alkali reactor) 
Karuppiah, R., Peschel, A., Grossmann, I.E., Martín, M., Martinson, W. Zullo, L., (2008) Energy optimization of an Ethanol Plant. AICHE J., 54, 1499-1525

Knoshaug, E.P.; Darzins, A: (2011) Algal Biofuels: The process. CEP. April 2011, 37-47

Krawczyk, T. (1996) Biodiesel Alternative Fuel Makes Inroads But Hurdles Remain, Inform 7 (8): 801-815

Landis, D.A., Gardiner, M.M., van der Werf, W., Swinton, S.M., 2008. Increasing corn for biofuel production reduces biocontrol services in agricultural landscapes. Proc. Natl. Acad. Sci. USA 105, 20552-20557.

Jian-Ming Lv , Li-Hua Cheng Xin-Hua Xu, Lin Zhang , Huan-Lin Chen (2010) Enhanced lipid production of Chlorella vulgaris by adjustment of cultivation conditions Bioresource Technology 101 (2010) 6797-6804

Barbora Maršálková, Marcela Širmerová, Michal Kuřec, Tomáš Brányik Irena Brányiková, Karel Melzoch, Vilém Zachleder (2010) Microalgae Chlorella sp. as an Alternative Source of Fermentable Sugars CHEMICAL ENGINEERING TRANSACTIONS Volume 21, 1279-1285

Martín, M.; Ahmetovic, E.; Grossmann, I.E. (2011) "Optimization of Water Consumption in Second Generation bioEthanol Plants " I\&ECR 50 (7), pp 3705-3721

Martin \& Grossmann (2011) Energy optimization of ethanol production via gasification. AlChE J. 57, 12, 3408, 3428

Martín, M., Grossmann, I.E. (2011) Energy optimization of Hydrogen production from biomass. Computers and chemical engineering, 35, 9, 1798-1806

Martin \& Grossmann (2012) Energy optimization of ethanol production via hydrolysis. AIChE J. 58 (5) 1538-1549

Martín, M., Grossmann, I.E. (2012) Simultaneous optimization and heat integration for biodiesel production from cooking oil and algae. Ind. Eng. Chem Res DOI: 10.1021/ie2024596

McKendry, P., 2002. Energy production from biomass (part 2): conversion technologies. Bioresour. Technol. 83, 4754.

Nigam, P. S., Singh, A., (2011) Production of liquid biofuels from renewable resources. Prog. Energy Combust. Sci. doi:10.1016/j.pecs.2010.01.003., 37, 1, 52-68

Piccolo, C., Bezzo, F., (2009) A techno-economic comparison between two technologies for bioethanol production from lignocelluloses. Biomass Bioener., 33, $478-491$

Powell, E.E., Hill, G.A., 2009. Economic assessment of an integrated bioethanol- biodiesel-microbial fuel cell facility utilizing yeast and photosynthetic algae. Chem. Eng. Res. Des. 87, 1340-1348.

Radich, A (2010) Biodiesel Performance, Costs, and Use http://tonto.eia.doe.gov/ftproot/environment/biodiesel.pdf accessed July 2010 (Electricity consumption)

Rodrigues, R.C., Volpato, G., Ayub, M. A. Z., Wada, K. (2008) Lipase-catalyzed ethanolysis of soybean oil in a solvent-free system using central composite design and response surface methodology $\mathrm{J}$ Chem Technol Biotechnol 83:849-854 (Model reaction enzyme)

Rosenberg, J.N., Oyler, G.A., Wilkinson, L., Betenbaugh, M.J., 2008. A green light for engineered algae: redirecting metabolism to fuel a biotechnology revolution. Biotechnology 19, 430-436 
Sawayama S, Inoue S, Dote Y, Yokoyama SY. 1995. CO2 fixation and oil production through microalgae.Energy Convers Manag. 36, 729-31.

Searchinger, T., Heimlich, R., Houghton, R.A., Dong, F., Elobeid, A., Fabiosa, J., Tokgoz,S., Hayes, D., Yu, T.H., 2008. Use of US croplands for biofuels increases greenhouse gases through emissions from land-use change. Science 319, 1238- 1240

Severson, K., Martin, M. Grossmann I.E (2012) Optimal production of biodiesel using bioethanol. AICHE J. DOI: 10.1002/aic. 13865

Sheehan, J., 2009. Engineering direct conversion of CO2 to biofuel. Nat. Biotechnol. 27, 1128-1129

Nivea de Lima da Silva, Cesar Benedito Batistella, Rubens Maciel Filho, and Maria Regina Wolf Maciel (2009) Biodiesel Production from Castor Oil: Optimization of Alkaline Ethanolysis Energy Fuels 2009, 23, 5636-5642 (model alkaliv)

Ueda, R., Hirayama, S., Sugata, K., Nakayama, H., 1996. Process for the production of ethanol from microalgae. US Patent 5,578,472.

USDA 2011 www.extension.iastate.edu/agdm

Waltz, E., 2009. Biotech's green gold? Nat. Biotechnol. 27, 15-18.

West, A.H.; Posarac, D.; Ellis, N. (2008) Assessment of four biodiesel production processes using HYSYS.Plant Bioresour. Technol. 99, 6587-6601

Wooley, R.J., Putsche, V. (1996) Development of an ASPEN PLUS Physical Property Database for Biofuels Components NREL/MP-425-20685 http://www.p2pays.org/ref/22/21210.pdf

Wooley, R., Ruth, M., Sheehan, J., Ibsen, K., Majdeski, H., Galvez, A (1999) Lignocellulosic biomass to ethanol process design and economics utilizing co-current dilute acid prehydrolysis and enzymatic hydrolysis current and futuristic scenarios NREL/ TP - 580- 26157

http://www.icispricing.com/il_shared/Samples/SubPage170.asp

Zhang, Y.; Dube, M. A.; McLean, D. D.; Kates, M. (2003) Biodiesel Production from Waste Cooking Oil: 1. Process Design and Technological Assessment. Bioresour. Technol., 89, 1-16.

Zhang, Y.; Dube, M. A.; McLean, D. D.; Kates, M. (2003) Biodiesel production from waste cooking oil: 2. Economic assessment and sensitivity analysis Bioresour. Technol. 90, 229-240

Zhang, S., Marechal, F., Gassner, M., Perin-Levasseur, Z., Qi, W., Ren, Z., Yan, Y., Favrat, D., (2009) Process Modeling and Integration of Fuel Ethanol Production from Lignocellulosic Biomass Based on Double Acid Hydrolysis. Energy Fuels, 23 (3), 1759-1765

Zorzetto, L.F.M., Filho, R. M., Wolf-Maciel, M. R., (2000) Process modeling development through artificial networks and hybrid models Comp. Chem. Eng. 24, 1355-1360 